\title{
The Relationship Between Perceptual Motor Skills and Attention ${ }^{1}$
}

\author{
Vanessa de Sousa ${ }^{2}$ \\ Universidade São Francisco, Itatiba-SP, Brazil
}

\author{
Fabián J. M. Rueda \\ Universidade São Francisco, Itatiba-SP, Brazil
}

\begin{abstract}
Although the relationship between perceptual motor skills and attention is reported in the literature, few studies have empirically explored this association. Thus, the objective of this study was to investigate the relationship between these constructs, using the Bender-Gestalt Test: Gradual Scoring System (B-SPG) and the Psychological Battery for Attention Assessment (BPA). The participants were 320 children from four public schools in a city located in the South of the state of Minas Gerais, with ages ranging from seven to 10 years $(M=8.39, S D=1.10)$ and $196(55.9 \%)$ female. The results showed negative, moderate and significant correlations between the total scores of the instruments, indicating the relationship between the constructs. Although the data has confirmed the existence of a relationship between perceptual motor skills and attention, further studies with samples from other regions are necessary.
\end{abstract}

Keywords: Bender Gestalt test, school age children, attention, psychological testing

\section{A Relação Entre a Habilidade Perceptomotora e Atenção}

\begin{abstract}
Resumo: Embora seja apontada na literatura a relação entre a habilidade perceptomotora e a atenção, poucos estudos exploraram empiricamente essa associação. Assim, o objetivo deste estudo foi verificar a relação entre esses construtos, por meio dos instrumentos Teste Gestáltico Visomotor de Bender: Sistema de Pontuação Gradual (B-SPG) e a Bateria Psicológica para Avaliação da Atenção (BPA). Os participantes foram 320 crianças de quatro escolas públicas de uma cidade situada no sul do estado de Minas Gerais, com idades que variaram entre sete e 10 anos $(M=8,39 ; D P=1,10)$, sendo $196(55,9 \%)$ do sexo feminino. Os resultados evidenciaram correlações negativas, moderadas e significativas entre os escores totais dos instrumentos, indicando a relação entre os construtos. Embora os dados tenham corroborado a existência de relação entre a habilidade perceptomotora e a atenção, considera-se necessária a realização de novos estudos com amostras de outras regiões.
\end{abstract}

Palavras-chave: teste Gestáltico de Bender, crianças em idade escolar, atenção, testes psicológicos

\section{La Relación Entre Habilidad Perceptomotora y Atención}

\begin{abstract}
Resumen: Aunque la literatura informe sobre la relación entre la habilidad perceptomotora y la atención, pocos estudios han explorado empíricamente esta asociación. El objetivo de este trabajo fue investigar la relación entre esos constructos, a través de los instrumentos Test Gestáltico de Bender: Sistema de Puntuación Gradual (B-SPG) y la batería de Psicología para la Evaluación de la Atención (BPA). Los participantes fueron 320 niños de cuatro escuelas públicas de una ciudad situada en el sur del estado de Minas Gerais, con edades que variaron de siete a 10 años $(M=8,39, D P=1,10)$, siendo $196(55,9 \%)$ niñas. Los resultados mostraron correlaciones negativas, moderadas y significativas entre las puntuaciones totales de los instrumentos, lo que indica la relación entre los constructos. Aunque los datos han confirmado la existencia de relación entre habilidad perceptomotora y atención, se considera necesario realizar nuevos estudios con muestras de otras regiones.
\end{abstract}

Palabras clave: test de Bender-Gestalt, niños en edad escolar, atención, tests psicológicos

Perceptual motor skills are related to the execution of different daily activities, permeating the individual's processes of interaction with the world (Wang et al., 2015). To execute tasks involving those skills, the individual needs

\footnotetext{
${ }^{1}$ Paper taken from the primary author's Master's thesis under the secondary author's supervision, defended in 2014 in the Stricto Sensu Graduate Program in Psychology at Universidade São Francisco.

Support: 33050015005P8

${ }^{2}$ Correspondence address:

Universidade São Francisco / Pós-Graduação Stricto Sensu em Psicologia, Faculdade de Ciências Humanas, USF. Rua Alexandre Rodrigues Barbosa, 45, Centro, CEP: 13251-900, Itatiba, SP-Brazil. E-mail: sousa.vanessa.psi@ gmail.com
}

visual acuity, the ability to perceive the different elements and their spatial relations, as well as appropriate motor skills (Zuccolo, Rzezak, \& Góis, 2010). In addition, the construct is associated with language, concepts of time and space, organizational and representational skills (Bender, 1955).

Bender (1955) and Koppitz (1963) report that the perceptual motor development occurs in parallel with the child's maturing. Hence, the tool to assess this development reveals more of the effect of a maturing process than of an educational process. Koppitz also mentions that the development of this skills starts from birth and is generally mature around the age of 11 years. In addition, according to 
Decker (2008), after this period, there is a slow decline in adult age and a steep decline in the further phases of life.

A contribution to the understanding of visual motor perception was proposed based on the Gestalt principles. In 1938, the psychiatrist Lauretta Bender developed a method the copy of gestaltic figures - to assess children's neurological maturing. As a reference for her work, Bender used the studies on perceptual phenomena by Max Wertheimer, one of the founders of the Gestalt Theory, who investigated the origin of the perception of form in children, based on the principles of this theory (Sisto, Noronha, \& Santos, 2005).

Nevertheless, Lauretta Bender worked with the clinical application of the test and did not propose a system to correct and assess the answers obtained. Therefore, some proposals were developed later to systemize the test, such as Brannigan and Brunner (2002), Hutt (1969/1998), Koppitz (1963) and Santucci and Pêcheux (1981), among others. In Brazil, in 2005, a new correction method for the Bender was developed, the Gradual Scoring System - B-SPG (Sisto et al., 2005).

Studies have shown the sensitivity of the B-SPG in samples from different Brazilian regions (Noronha, Rueda, \& Santos, 2015). In addition, the system has been used in Peruvian samples and the results appointed its suitability as an assessment measure of perceptual motor skill (Rueda, Santos, Noronha, \& Segovia, 2013; Santos, Noronha, Rueda, \& Segovia, 2014). The B-SPG has been correlated with different constructs, such as intelligence (Noronha, Santos, \& Rueda, 2013), learning to write (Suehiro \& Santos, 2005) and read (Carvalho, Noronha, Pinto, \& Luca, 2012).

Furthermore, the relation between perceptual motor skill and age has been empirically verified. In a study involving 1053 children from the interior of the State of São Paulo, a moderate and negative correlation was found between the B-SPG and the participants' ages (Sisto et al., 2005). In the same sense, Pinto and Noronha (2010) investigated the performance of 298 children and found a moderate and negative correlation among the variables. Those data are in line with the premise of the tool in that, as age increases, the distortions in the quality of the test drawings fade out.

Perceptual motor skills are involved in the development of different aspects, such as language and space and time concepts (Bender, 1955). In addition, in the literature, the relation between the perceptual motor skills and attention, as the latter is a concept that refers to the perception of stimuli, being closely related with perception (Penna, 1984). In the same sense, Pessoa, Kastner and Ungerleider (2003) refer that the goal of attention is to enhance the perceptual skills so that a certain target is distinguished.

Attention is considered as the ability of the organism to actively process a quantity of information among the countless stimuli it has contact with through the senses, memories and other cognitive processes (Sternberg, 2000). Some of the most cited types of attention in the literature are concentrated, divided and alternating attention. Concentrated attention refers to the ability to select but one stimulus, to the detriment of others, for a certain period of time. Alternating attention refers to the ability to successively substitute the focus among stimuli. Divided attention, in turn, refers to the ability to divide the focus among different stimuli simultaneously (Rueda, 2013).

Although few studies have been developed in which both constructs were considered, in the international literature, the study by Schultz et al. (1998) was found, which sought empirical evidence for the conception of attention as one of the subprocesses of the perceptual motor ability. The authors assessed children between eight and 14 years of age. To assess the visual-motor integration, the Beery-Buktenica VisualMotor Integration Test (VMI) and the Rey-Osterreith Complex Figure (Rey) were used and, to assess sustained attention, the Computer-Administered Continuous Performance Test (CPT). The results evidenced that sustained attention was not significantly correlated with the visual-motor integration measures. Hence, these findings did not support the scheme the authors proposed. Nevertheless, the researchers consider that more in-depth studies are needed, using other tools, before concluding that attention is not an essential component in the perceptual-motor integration process.

Soto (2011) verified the relation between the visualmotor ability, assessed using the Modified Bender-Gestalt Test and attention using the Caras Test, which assesses the perception of similarities and differences in facial patterns through a cancelation test that provides percentage estimates of speed and attention. The study sample consisted of 90 children between five and eight years of age. The results indicated that sustained attention, required for the Caras Test, is not associated with the performance of the TGB-M. The author considered that the high degree of specificity of attention tasks in a context of speed can justify a non-shared variance between the two constructs in question. In addition, the same author considers that the extent of the relation between these skills can change due to the difference in the methods to assess each.

Even if the research by Soto (2011) reveals little association between the construct, the notion that attention is a basic process of all cognitive activity (Sternberg, 2000) suggests that it is also fundamental in perceptual-motor ability. In line with this idea, Schultz et al. (1998) defend that attention is part of this ability. This conception is also shared by Fonseca (2008), who guarantees that attention loss interferes in the perceptual and motor functions.

In the school context, both the perceptual-motor ability (Carvalho et al., 2012; Suehiro \& Santos, 2005) and attention (Capovilla \& Dias, 2008) have been associated with academic performance. On the one hand, Capovilla and Dias (2008) report that attention difficulties can cause global adaptation difficulties, besides being specifically associated with learning process at school age. On the other, Germano, Pinheiro, Okuda and Capellini (2013) emphasize the importance of perceptual-motor skills in the acquisition of writing, due to the need to coordinate visual information and motor programming required in this learning. The constructs were jointly assessed in clinical populations, evidencing their associations with the Attention Deficit Disorder with Hyperactivity (Allen \& Decker, 2008; Germano et al., 2013) and with Tourette's Syndrome (Schultz et al., 1998).

As the studies cited did not involve a Brazilian sample 
and did not use the B-SPG, it was considered important to explore the problem using the B-SPG and the Psychological Battery for Attention Assessment (BPA), which permits the investigation of three attention modalities. Hence, the general objective in this study was to verify the relation between perceptual-motor ability and attention using the B-SPG and BPA tests. The results can produce validity evidence for both tools. The specific objectives were to seek validity evidence based on the relations with external variables - tests that assess related constructs, that is, perceptual-motor ability, concentrated, divided and alternating attention and general ability and age.

Table 1

Distribution of Participants per Age

\begin{tabular}{|c|c|c|c|c|}
\hline \multirow{2}{*}{ Age } & \multicolumn{2}{|c|}{ Sex } & \multirow{2}{*}{ Total } & \multirow{2}{*}{$\%$} \\
\hline & Male & Female & & \\
\hline 7 & 41 & 48 & 89 & 27.8 \\
\hline 8 & 35 & 48 & 83 & 25.9 \\
\hline 9 & 37 & 46 & 83 & 25.9 \\
\hline 10 & 28 & 37 & 65 & 20.4 \\
\hline Total & 141 & 179 & 320 & 100.0 \\
\hline
\end{tabular}

\section{Instruments}

Visual-Motor Bender-Gestalt Test: Gradual Scoring System (B-SPG; Sisto et al., 2005). The B-SPG serves to assess the perceptual-motor maturity of children between six and 10 years of age through the reproduction of drawings. The tool consists of nine figures that, to execute the test, should be copied on a white sheet of paper without mechanical help. The assessment criterion is the distortion of the shape. In addition, its scoring is gradual, so that zero points are attributed when there are no errors, while scores 1,2 and 3 indicate gradually larger problems in the quality of the drawing.

Psychometric studies have been developed using the B-SPG. Validity evidence was verified based on the internal structure, through the analysis of Differential Item Functioning (DIF), with a view to verifying if people with the same level of skill react to the test differently because they belong to different groups. The results showed that, among the 10 images studied, only two differed the sex, figures 5 and 6 . The boys tended towards a higher score, indicating more distortions in figure 5, while the girls had more difficulty to execute figure 6 . The authors chose to maintain both figures, considering that the items compensated one another. In addition, the test score was related to the children's age, with a significant coefficient, according to the classical theory ( $r=$ $-.58)$ as well as the Rasch measure $(r=-.60)$, evidencing that, as age increases, the distortions in the Bender-SPG decreased. The precision ratios were calculated by means of the Rasch measure (.76), Cronbach's alpha (.80) and Spearman-Brown's split-half procedure (.77).

Psychological Battery for Attention Assessment (BPA; Rueda, 2013). This tool serves for people as from the age

\section{Method}

\section{Participants}

The sample consisted of 320 children from four public schools in a city in the South of Minas Gerais, 55.94\% of whom were girls. Two schools were located in the central region of the city and the remaining two on the outskirts. Ages ranged between seven and 10 years $(M=8.39$; $S D=$ 1.10) with a homogeneous distribution, as can be observed in Table 1. of six years. The objective is to assess the general attention ability and provide individual results for Concentrated Attention (CA), Divided Attention (DA) and Alternating Attention (AA).

For each test, one or more target stimuli exist, arranged amidst various distracting stimuli. In the CA test, the person is expected to draw a line each time an image appears that is equal to a set model. In DA, three target stimuli are presented that should be marked whenever they are present, whether together or not. In the AA, the target stimulus is presented next to each test line and the person should mark a specific image for each line.

As regards the psychometric studies, the BPA demonstrated its sensitivity to distinguish among different age ranges of subjects between six and 82 years of age. Concerning the relation with other constructs, the correlation coefficients with a test to assess the visual-spatial reasoning ranged from .20 to .29 . With regard to intelligence, the correlations with the $\mathrm{R} 1$ test varied between .31 and .45 . The $\mathrm{R} 1$ test is a two-factor tool, the first being associated with crystallized intelligence and the second with the g-factor. In addition, the correlations between the tests that are part of the BPA were all positive and statistically significant and moderate. As verified, each of the tests (CA, DA and AA) has more than $70 \%$ of communality with the general battery measure. Concerning the precision ratios, the correlation coefficients according to the test-retest method varied between .68 and .89 .

\section{Procedure}

Data collection. After approval by the Ethics Committee, the schools were contacted to distribute the Free and Informed Consent Forms (FICF) to the children. 
When the FICF was delivered, the objectives and collection procedure were clarified, besides the non-compulsory nature of their participation. Students who handed in the FICF signed by the parents or responsible caregivers were taken to a classroom where the tools were applied in a group. The data were collected during a single session with the help of two psychology students, who received background training to execute the activities. The tools were applied in groups of 25 children at most.

The order in which the tests were applied alternated, as $49.9 \%$ of the children performed the B-SPG first, followed by the BPA. In the rest of the sample, the application was the opposite, starting with the BPA, followed by the B-SPG. This procedure was adopted to minimize possible interference of the fatigue effect in the children's performance on the test applied last.

The protocols were corrected according to the instruction manual. It was taken into account that the correction of the B-SPC can involve, even if minimally, the evaluator's subjectivity. Therefore, the precision was checked between two evaluators, asking a previously trained judge to blind review $30 \%$ of the protocols. The resource was used to assess the reliability of the correction process.

Data analysis. First, the precision between the two evaluators was verified using Pearson's correlation coefficient. Then, the descriptive statistics of the B-SPG and BPA were calculated. The one sample $t$ test was applied to check for statistically significant differences between the samples in the instruction manuals and the study sample. Variance analysis (ANOVA) was used to look for differences in function of age, followed by Tukey's post-hoc test for multiple comparison of means. In addition, the effect magnitudes were presented using eta squared. Pearson's correlation was also used to verify the relation between the constructs.

\section{Ethical Considerations}

The project that originated this study was submitted to the Research Ethics Committee at Universidade São Francisco, in compliance with National Health Council Resolution 196/96 (CAAE: 20460113.6.0000.5514), in force at the time of the study. The data collection started after the committee had given its approval.

Table 2

Tukey's test, F, $p$ and $\eta_{p}{ }^{2}$ values in Function of Age

\begin{tabular}{|c|c|c|c|c|c|c|c|c|c|c|}
\hline \multirow{2}{*}{ Tests } & \multirow[b]{2}{*}{ gl } & \multirow[b]{2}{*}{$F$} & \multirow[b]{2}{*}{$p$} & \multirow[b]{2}{*}{$\eta_{p}^{2}$} & \multirow{2}{*}{ Age } & \multirow{2}{*}{$N$} & \multicolumn{4}{|c|}{ Subgroups for alpha $=.005$} \\
\hline & & & & & & & 1 & 2 & 3 & 4 \\
\hline \multirow{5}{*}{ B-SPG } & 3 & 16.78 & .001 & .14 & 10 years & 65 & 8.23 & & & \\
\hline & & & & & 8 years & 83 & 8.89 & & & \\
\hline & & & & & 9 years & 83 & 9.10 & & & \\
\hline & & & & & 7 years & 89 & & 11.80 & & \\
\hline & & & & & $P$ & & .406 & 1.00 & & \\
\hline
\end{tabular}

\section{Results}

First, the results of the B-SPG protocols assessed by the researcher and the judge were compared. For the total In addition, Student's t-tests were applied between the mean scores of the children who execute the tests in one or the other application order. The results indicated no statistically significant difference between the groups $(t=-.98, p=.33$ $/ t=-1.12, p=.27$ ) concerning the total B-SPG and BPA scores, respectively. Considering that the correction of the protocols was reliable and that there were no differences between the application orders of the tests, further analyses were undertaken.

In view of the objectives, first, the descriptive statistics of the B-SPG and BPA will be presented. Next, the comparisons of means in function of age will be shown. Finally, the correlations between the tools will be presented for the general sample and per age.

For the general population, the mean B-SPG score was $9.62(S D=3.74)$ and the score ranged from zero to 20 . The most frequent score was nine points, totaling $14.1 \%$ of the sample. When comparing this information with that of the sample in the test manual, the performance of the sample in this research was statistically inferior to the normative sample when considering the seven-year-old boys $(t=2.98, p<.01)$, the nine-year-old boys $(t=3.47, p<.01)$ and girls $(t=3.38$, $p<.01)$, and ten-year-old boys $(t=2.55, p<.01)$ and girls $(t=6.22, p<.01)$. It should be highlighted that, the lower the score, the better the performance on the test, as points are attributed to the errors made.

On the BPA, the mean general score was 146.32 and the standard deviation 44.41 . It was also observed that $50 \%$ of the children scored up to 145 . The mean scores on the CA, DA $=19.39) ; 52.63(S D=18.22)$, respectively. When compared to the score of the normative sample - age range from six to 10 years - it was verified that our sample performed significantly better on all tests: DA $(t=8.98, p<.01)$, AA $(t$ $=6.70, p<.01)$ and General Attention tests $(t=7.33, p<.01)$. As the instruction manual does not include the data for each age separately, the differences of means considering each age distinctly could not be verified.

To check for differences among the mean scores related to age, the data were submitted to ANOVA. Table 2 displays the results of this analysis. test score, the correlation between both was high $(r=.90)$. and AA tests corresponded to $47.69(S D=15.06) ; 46.00(S D$ 
Paidéia, 27(66), 24-32

...continuation

\begin{tabular}{|c|c|c|c|c|c|c|c|c|c|c|}
\hline \multirow{2}{*}{ Tests } & \multirow[b]{2}{*}{ gl } & \multirow[b]{2}{*}{$F$} & \multirow[b]{2}{*}{$p$} & \multirow[b]{2}{*}{$\eta_{p}^{2}$} & \multirow{2}{*}{ Age } & \multirow{2}{*}{$N$} & \multicolumn{4}{|c|}{ Subgroups for alpha $=.005$} \\
\hline & & & & & & & 1 & 2 & 3 & 4 \\
\hline \multirow{5}{*}{ Attention General } & 3 & 41.13 & .001 & .28 & 7 years & 89 & 116.93 & & & \\
\hline & & & & & 8 years & 83 & & 138.95 & & \\
\hline & & & & & 9 years & 83 & & & 156.64 & \\
\hline & & & & & 10 years & 65 & & & & 182.80 \\
\hline & & & & & $P$ & & 1.00 & 1.00 & 1.00 & 1.00 \\
\hline \multirow{5}{*}{$\mathrm{AC}$} & 3 & 28.76 & .001 & .21 & 7 years & 89 & 38.64 & & & \\
\hline & & & & & 8 years & 83 & & 45.55 & & \\
\hline & & & & & 9 years & 83 & & & 51.71 & \\
\hline & & & & & 10 years & 65 & & & & 57.69 \\
\hline & & & & & $p$ & & 1.00 & 1.00 & 1.00 & 1.00 \\
\hline \multirow{5}{*}{$\mathrm{AD}$} & 3 & 16.16 & .001 & .13 & 7 years & 89 & 37.02 & & & \\
\hline & & & & & 8 years & 83 & & 45.17 & & \\
\hline & & & & & 9 years & 83 & & 47.78 & & \\
\hline & & & & & 10 years & 65 & & & 57.46 & \\
\hline & & & & & $P$ & & 1.00 & .85 & 1.00 & \\
\hline \multirow{5}{*}{ AA } & 3 & 40.99 & .001 & .28 & 7 years & 89 & 41.27 & & & \\
\hline & & & & & 8 years & 83 & & 48.23 & & \\
\hline & & & & & 9 years & 83 & & & 57.45 & \\
\hline & & & & & 10 years & 65 & & & & 67.65 \\
\hline & & & & & $P$ & & 1.00 & 1.00 & 1.00 & 1.00 \\
\hline
\end{tabular}

All differences were significant. The analysis of which groups were involved in the differences showed that, in the B-SPG, two mutually distinct sets are constituted, with sevenyear-olds obtaining a significantly higher mean score than the other children. Concerning the BPA, four groups were constituted with significantly distinct means on the CA, AA and General Attention. In these cases, all ages differed, the lowest means relating to seven-year-olds and the highest to ten-year-old children. Only three groups were found for the DA test, the first consisting of seven-year-olds, the second of eight and nine-year-olds and the third of ten-year-old children.

To verify the relation between the constructs the tools measure, Pearson's correlation test was used. The data for the general sample and organized per age are displayed in Table 3.

Table 3

Correlation Matrix Between B-SPG and BPA

\begin{tabular}{ccccc}
\hline Age & AC & AD & AA & General Attention \\
\hline $7(n=89)$ & -.13 & $-.21^{*}$ & $-.30^{* *}$ & $-.28^{* *}$ \\
$8(n=83)$ & -.12 & $-.23^{*}$ & $-.29 * *$ & $-.27^{*}$ \\
$9(n=83)$ & $-.42 * *$ & $-.40^{* *}$ & $-.44^{* *}$ & $-.50^{* *}$ \\
$10(n=65)$ & .08 & -.13 & $-.35^{* *}$ & -.17 \\
Total $(N=320)$ & $-.28^{* *}$ & $-.34^{* *}$ & $-.44^{* *}$ & $-.42^{* *}$ \\
\hline
\end{tabular}

${ }^{*} p<.05 . * * p<.01$.

For the total sample, the B-SPG correlation coefficients were statistically significant but weak when related to the CA and DA and moderate when associated with the AA and General Attention, in view of the classification by Dancey and Reidy (2013). The highest coefficients were found for nineyear-olds. These were all statistically significant, positive and moderate. When considering seven and eight-year-olds, the correlations were weak for all BPA scores, being significant for DA, AA and General Attention. At the age of ten years, all coefficients were weak and the results were significant only for the AA test. It is also relevant to highlight that all AA coefficients were statistically significant and ranged between weak and moderate. 


\section{Discussion}

The objective was to empirically verify the relation between perceptual-motor skill and attention using the B-SPG and BPA. In addition, it was analyzed how these constructs relate to the age variable. In addition, performance differences were analyzed between the study sample and the normative sample.

As for perceptual-motor maturity, the performance of the present sample was inferior at the ages of seven, nine and ten years. The fact that all of these children came from public schools, differently from the normative sample with public and private-school children, may justify the performance difference. Concerning attention, the normative sample - also from public and private schools - performed worse than the present research sample. This result can be explained though, considering that the normative sample included six-year-olds, while the present sample started at age seven.

What the maturation is concerned, both tools revealed that, as age advances, the task performance improves significantly. As for the B-SPG, in which the scores refer to the errors, the mean scores dropped as the ages increased. The differences of means in terms of age were statistically significant. Also, the eta squared $\left(\eta p^{2}=.14\right)$ indicates the strong effect of the differences according to Cohen (1998). Bender (1955) advocated the evolutionary nature of the test, indicating that the perceptual-motor ability is related to children's neurological maturing process. This aspect was maintained in the B-SPG proposal, in accordance with Pinto and Noronha (2010) and Sisto et al. (2005).

Regarding the BPA, better performance on the battery was also verified as age advanced. On all tests, significant differences of means were found in terms of age. Eta squared coefficients ranged between .13 and .28, indicating moderate to strong effects according to Cohen (1998). These data are in line with the premises found in the literature, alleging that the ability to focus and inhibit stimuli, typical of attention, is enhanced as a result of cerebral development (Richards, 2005).

To verify the association between the research constructs, the B-SPG and BPA measures were correlated. According to Nunes and Primi (2010), the expected correlations between tools that assess related constructs range between 0.20 and 0.50 . The results showed that the total correlations between the tests were negative and statistically significant, with coefficients ranging between -.28 and -.42 , indicating that the tests measure some shared elements. It was verified that the shared variance between the constructs corresponded to $7.84 \%$ for the CA test; $11.56 \%$ for the DA test; $19.36 \%$ for the AA test and $17.64 \%$ for General Attention. As observed, the highest coefficient referred to Alternating Attention and the lowest to Concentrated Attention, suggesting that the task of perceiving and copying images seems to be more linked to alternating attention and less to concentrated attention. This finding is understandable when considering that, in the execution of the B-SPG, the child should alternate the focus of attention between the projected image and the drawing of the image to copy the design.

When these measures were observed in view of the participants' ages, higher coefficients were found at the age of nine years, ranging from - .42 to -.50 , with statistical significance. These study results are in line with authors who report on the association between the research constructs (Fonseca, 2008; Penna, 1984; Pessoa et al., 2003). On the other hand, the data observed differ from the findings in Schultz et al. (1998) and Soto (2011). Nevertheless, in the study by Schultz et al., some particularities can be appointed. First, the Beery-Buktenica Visual-Motor Integration Test (VMI) e Rey-Osterreith Complex Figure (Rey) were used to assess the visual-motor integration and, although both use the image copy technique to assess the ability - like the Bender, the authors weigh the results, considering that the abilities in question, when correlated by means of other tools, could provide different results.

Another point to be taken into account in the study by Schultz et al. (1998) is the sample, which consisted of participants between eight and 14 years of age, different from the present sample, with participants between seven and 10 years of age. This aspect is relevant as, in the present study, it was observed that, when considering the older children (10 years), the correlations between the tools were smaller than the others - except for Alternating Attention, for which the lowest coefficients were observed at the ages of seven and eight years. Hence, one may think that, if the relation between general attention and perceptual-motor ability tends to drop as from the age of 10 years, this could justify the result found by Schultz et al., due to the age characteristic of that sample.

In this respect, it should be highlighted that perceptualmotor ability is developed more or less until the age of 11 years, in accordance with Koppitz (1963). Attention, on the other hand, is continuously developed until the start of adult age, according to Richards (2005). In addition, if the development of perceptual-motor ability nearly stabilizes at the age of 10 years, one might consider that the reproduction of the images is an easier task for those children when compared to younger ones. Hence, the execution of this activity at that age can require less attention. These considerations can justify the more enhanced correlation between the abilities in question until the age of nine years, followed by a drop.

It should also be kept in mind, with regard to the study by Schultz et al. (1998), that a computerized test of sustained attention was used to assess the attention. In other words, the fact that the general test score was calculated in a certain way - by adding up the scores for concentrated, divided and alternating attention, like in the case of the BPA; or that the test score derived from a task that assesses sustained attention, like in the case of the CPT - can influence the calculation of the common variance between the constructs. Also, the execution of both attention tests is different, as one is computerized - the individual has to press a button when a certain stimulus is present - and the other graphical, in which the individual has to draw a line on a sheet of paper when the target stimulus is visualized. Both tasks do not presupposed equivalent execution skills.

As regards the research by Soto (2011), the author 
correlates the perceptual-motor skill according to the TGB-M and attention based on the Caras Test, observing that the shared variance between the measures is nil. According to the author, the research results may have been due to the specificity of the attention tests in contexts of speed. In this study, however, in which the attention tests also involve speed, the relation between the constructs could be verified. Hence, one might think that the specificity of the Caras Test, which may have influenced the relations between the construct, is more due to the recognition process of facial patterns than to the speed the test requires. In the same sense, it is important to mention that facial recognition is commonly associated with social cognition (Rodríguez Sosa, Acosta Ojeda, \& Rodríguez Del Rosario, 2011). Hence, one may think that social cognition - besides attention and perceptual speed - also influences the performance on the Caras Test, which could justify the difference between the research results.

In view of the results of this study, the execution of the drawings Bender (1955) proposed involve attention, keeping in mind that, according to Pessoa et al. (2003), attention plays the role of enhancing the perceptual sensitivity to distinguish a certain target. In addition, one may consider the possible interference of the perceptual-motor ability in the accomplishment of cancelation tasks involved in attention tests like the BPA. In that sense, the position of Spreen and Strauss (1998) should be mentioned, who argue that motor aspects are normally involved in attention tests and that this fact should be taken into account to assess this cognitive process.

This study was proposed to contribute to research on the psychometric properties of Brazilian tools. The relation between the B-SPG, a measure of perceptual-motor maturity, and the BPA, a measure of attention, was verified. The empirical demonstration of the relation between the constructs these tools assess is relevant as it enhances the possible interpretation and range of the two tests, considering that both measures are involved in the school context (Carvalho et al., 2012; Suehiro \& Santos, 2005) and in clinical conditions (Allen \& Decker, 2008; Germano et al., 2013; Schultz et al., 1998). In both cases, studies to explore the theoretical relation between these two constructs are considered important, also taking into account the practical implications of these findings for professionals engaged in child development, in the school and clinical contexts. That is so because knowledge on the relations between the skills involved in children's cognitive processes can lead to more effective interventions in case of losses in any of these skills. In addition, further research is relevant to study a combination with other constructs that may be related to perceptual-motor ability and attention. In view of the differences between the two samples, further normative research is considered relevant to update the data and analyze possible performance differences in distinct generations. Furthermore, future studies are needed involving samples from other Brazilian regions.

Some methodological care taken in the elaboration of the study should be highlighted. The first relates to the application of the tools, considering the alternated order of execution, which permitted verifying whether the fatigue effect influenced the test results. The other point refers to the attempt to guarantee the reliability of the B-SPG correction, which to a certain extent involves the evaluator's subjectivity. On the other hand, the study was limited by the fact that, despite the sample of 320 children, the number of participants for each age was not that representative. Also, only children from public schools participated. Another limitation was the absence of some information at the time of the data collection. For example, data on possible diagnoses or symptoms of conditions like Attention Deficit Disorder with Hyperactivity and Learning Disorders were not consulted, which could complement the study and serve as inclusion/exclusion criteria for the sample, or even to check for possible intergroup differences. In addition, socioeconomic data of the children and their respective families could have been verified.

In view of the data that support the relation between the constructs, this study offered validity evidence for both tools. These were based on the association between tests that assess related constructs and on the external variable age.

\section{References}

Allen, R. A., \& Decker, S. L. (2008). Utility of the Bender Visual-Motor Gestalt Test-Second Edition in the assessment of attention-deficit/hyperactivity disorder. Perceptual and Motor Skills, 107(3), 663-675. doi:10.2466/PMS.107.3.663-675

Bender, L. (1955). Test Gestáltico Visomotor - Usos y aplicaciones clinicas [Visomotor Gestalt Test - clinical uses y applications] (6th ed.). Buenos Aires, Argentina: Paidós.

Brannigan, G. G. \& Brunner, N. A. (2002). Guide to the Qualitative Scoring Systems for the Modified Version of the Bender-Gestalt Test. Springfield, IL, US: Charles C. Thomas, Publisher.

Capovilla, A. G. S., \& Dias, N. M. (2008). Desenvolvimento de habilidades atencionais em estudantes da $1^{\text {a }}$ série do ensino fundamental e relação com rendimento escolar [Attentional skills development in $1^{\text {st }}$ to $4^{\text {th }}$ levels students of elementary school and relation with scholar achievement]. Revista Psicopedagogia, 25(78), 198-211. Retrieved from http://pepsic.bvsalud.org/pdf/psicoped/ v25n78/v25n78a03.pdf

Carvalho, L., Noronha, A. P. P., Pinto, L. P., \& Luca, L. (2012). Maturidade perceptomotora e reconhecimento de palavras: Estudo correlacional entre o Bender - Sistema de Pontuação Gradual e o Teste de Reconhecimento de Palavras [Perceptive-motor maturity and word recognition: A correlational study between Bender - Scoring System for Grades and Word Recognition test]. Estudos de Psicologia (Campinas), 29(3), 371-377. doi:10.1590/ S0103-166X2012000300007

Cohen, J. (1988). Statistical power analysis for the behavioral sciences (2nd ed.). Hillsdale, NJ: Lawrence Erlbaum.

Dancey, C. P., \& Reidy, J. (2013). Estatística sem matemática 
para psicologia [Statistics without maths fo Psychology] (L. Viali, Trad., 5th ed.). Porto Alegre, RS: Penso.

Decker, S. L. (2008). Measuring growth and decline in visualmotor process with the Bender-Gestalt Second Edition. Journal of Psychoeducational Assessment, 26(1), 3-15. doi:10.1177/0734282907300685

Fonseca, V. (2008). Desenvolvimento psicomotor e aprendizagem [Psychomotor development and learning]. Porto Alegre, RS: Artmed.

Germano, G. D., Pinheiro, F. H., Okuda, P. M. M., \& Capellini, S. A. (2013). Percepção viso-motora de escolares com Transtorno do Déficit de Atenção com Hiperatividade [Visual-motor perception in students with Attention Deficit with Hyperactivity Disorder]. CoDAS, 25(4), 337341. doi:10.1590/S2317-17822013000400007

Hutt, M. L. (1998). La adaptacion Hutt del Test Guestaltico Bender [The Hutt Adaptation of the Bender Gestalt Test]. 4. ed. Buenos Aires: Guadalupe.

Koppitz, E. M. (1963). The Bender Gestalt Test for young children. New York, NY: Grune \& Stratton.

Noronha, A. P. P., Rueda, F. J. M., \& Santos, A. A. A. (2013). Bender Gestalt Visual-Motor test Sistema de Pontuação Gradual (B-SPG): A study with different samples. Paidéia (Ribeirão Preto), 23(55), 179-185. doi:10.1590/198243272355201305

Noronha, A. P. P., Rueda, F. J. M., \& Santos, A. A. A. (2015). Diferenças regionais e as normas de interpretação do Teste de Bender-Sistema de Pontuação Gradual [Regional differences and the standards of Bender-Gradual Scoring System Test]. Psicologia em Pesquisa, 9(1), 03-09. doi: 10.5327/Z1982-1247201500010002

Noronha, A. P. P., Santos, A. A. A., \& Rueda, F. J. M. (2013). Habilidad viso-motriz y deficiencia intelectual: Estudio de validez para el Bender-SPG [Visual motor ability and intellectual disabilities: Validity study of the BenderSPG]. Acta Colombiana de Psicología, 16(2), 115-123. doi:10.14718/ACP.2013.16.2.11

Nunes, C. H. S. S., \& Primi, R. (2010). Aspectos técnicos e conceituais da ficha de avaliação dos testes psicológicos [Technical and conceptual aspects of the assessment form of psychological tests]. In Conselho Federal de Psicologia (Org.), Avaliação psicológica: Diretrizes na regulamentação da profissão [Psychological assessment: Guidelines on regulation of the profession] (pp. 101-127). Brasília, DF: CFP.

Penna, A. G. (1984). Introdução à psicologia cognitiva [Introduction to cognitive psychology]. São Paulo, SP: EPU.

Pessoa, L., Kastner, S., \& Ungerleider, L. G. (2003). Neuroimaging studies of attention: From modulation of sensory processing to top-down control. The Journal of Neuroscience, 23(10), 3990-3998. Retrieved from http:// www.jneurosci.org/content/23/10/3990.full
Pinto, L. P., \& Noronha, A. P. P. (2010). Maturidade perceptomora e sua relação com idade e variáveis contextuais: Um estudo com o Bender (B-SPG) [BenderGradual Scoring System (B-SPG): Analysis of the maturation of visual-motor perception of children]. Encontro: Revista de Psicologia, 13(19), 145-155. Retrieved from htt?//sare.anhanguera.com/index.php/ rencp/article/download/3003/1244

Richards, J. E. (2005). The development of sustained attention in infants. In M. I. Posner (Ed.), Cognitive neuroscience of attention (pp. 342-356). New York, NY: Guilford.

Rodríguez Sosa, J. T., Acosta Ojeda, M., \& Rodríguez Del Rosario, L. (2011). Teoría de la mente, reconocimiento facial y processamiento emocional en la esquizofrenia [Theory of mind, facial recognition and emotional processing in schizophrenia]. Revista de Psiquiatría y Salud Mental, 4(1), 28-37. doi:10.1016/j.rpsm.2010.11.005

Rueda, F. J. M. (2013). Bateria Psicológica para Avaliação da Atenção (BPA) [Psychological Battery for Assessment of Attention (BPA)]. São Paulo, SP: Vetor.

Rueda, F, J. M., Santos, A. A. A., Noronha, A. P. P., \& Segovia, J. L. (2013). Estudio transcultural con la prueba de Bender: Sistema de pontuação gradual [Cross-cultural study with Bender Test: Gradual scoring system]. Liberabit, 19(2), 173-180. Retrieved from http://www.scielo.org.pe/scielo. php?pid=S1729-48272013000200003\&script=sci_arttext

Santos, A. A. A., Noronha, A. P. P., Rueda, F, J. M., \& Segovia, J. L. (2014). Bender-gradual scoring system: Performance of Brazilian and Peruvian children. Perceptual and Motor Skills, 118(3), 897-908. doi:10.2466/03.10. PMS.118k25w7

Santucci, H., \& Pêcheux, M. G. (1981). Prova Gráfica de Organização Perceptiva para crianças de 6 a 14 anos [Perceptual Organization Graphic Proof for children 6 to 14 years]. In R. Zazzo (Org.), Manual para o exame psicológico da criança [Manual for the psychological examination of the child] (pp. 291-338). São Paulo: Editora Mestre Jou.

Schultz, R. T., Carter, A. S., Gladstone, M., Scahill, L., Leckman, J. F., Peterson, B. S., ... Pauls, D. (1998). Visual-motor integration functioning in children with Tourette syndrome. Neuropsychology, 12(1), 134-145. doi:10.1037/0894-4105.12.1.134

Sisto, F. F., Noronha, A. P., \& Santos, A. A. A. (2005). Manual Bender - Sistema de Pontuação Gradual (B-SPG) [Manual Bender - Gradual Scoring System (B-SPG)]. São Paulo, SP: Vetor.

Soto, C. M. (2011). Test Gestáltico Visomotor de Bender modificado y Test de Caras: Una evaluación de la validez de constructo [Bender gestalt visualmotor test and caras test: A exam of construct validity]. Cadernos de Neuropsicología, 5(2), 129-143. Retrieved from http:// www.cnps.cl/index.php/cnps/article/view/125/112 
Spreen, O., \& Strauss, E. (1998). A compendium of neuropsychological tests: Administration, norms, and commentary (2nd ed.). New York, NY: Oxford University Press.

Sternberg, R. J. (2000). Psicologia cognitiva [Cognitive psychology] (R.C. Costa, Trad.). Porto Alegre, RS: Artes Médicas.

Suehiro, A. C. B., \& Santos, A. A. A. (2005). O Bender e as dificuldades de aprendizagem: Estudo de validade [The Bender and learning difficulties: Validity criteria study]. Avaliação Psicológica, 4(1), 23-31. Retrieved from http://pepsic.bvsalud.org/scielo.php?pid=S167704712005000100004\&script $=$ sci_arttext

Wang, L., Krasich, K., Bel-Bahar, T., Hughes, L., Mitroff, S. R., \& Appelbaum, L. G. (2015). Mapping the structure of perceptual and visual-motor abilities in healthy young adults. Acta Psychologica, 157, 74-84. doi:10.1016/j. actpsy.2015.02.005

Zuccolo, P. F., Rzezak, P., \& Góis, J. O. (2010). Praxia e visuoconstrução [Praxis and visuoconstructive]. In L. F. Malloy-Diniz, D. Fuentes, P. Matos, \& N. Abreu (Eds.), Avaliação neuropsicológica [Neuropsychological assessment] (pp. 114-122). Porto Alegre, RS: Artmed.

Vanessa de Sousa is a Ph.D. candidate from the Graduate Program in Psychology of the Universidade São Francisco.

Fabián J. M. Rueda is a Professor of the Universidade São Francisco.

Received: May 12, 2015

1st Revision: Oct. 27, 2015

2nd Revision: Nov. 2, 2015

Approved: Feb. 23, 2016

How to cite this article:

Sousa, V., \& Rueda, F. J. M. (2017). The relationship between perceptual motor skills and attention. Paidéia (Ribeirão Preto), 27(66), 24-32. doi: 10.1590/198243272766201704 